\title{
Aminoquinolone WR6026 as a feasible substitute for gentian violet in Chagas' disease prophylaxis in preserved blood for transfusional purposes
}

\author{
O emprego da aminoquinolina WR6026 como substituto incolor da violeta \\ de genciana na profilaxia da doença de Chagas transfusional \\ Helio Moraes-Souza ${ }^{1,2,3}$, Gisele Marilia Pianetti ${ }^{1,2,3}$, Orlando César de Oliveira \\ Pereira Barretto $^{4,5}$, Kimyo Nonoyama ${ }^{4,5}$, M. Grolg $^{6}$ and Egler Chiari ${ }^{7}$
}

\begin{abstract}
The search for a colorless, nontoxic and efficient drug to prevent transfusion-associated Chagas' disease (TACD) has been underway unsuccessfully since 1953 when gentian violet was preconized and to date is still being used as the only in vitro trypanocidal agent. The recent findings of aminoquinolone "WR6026" as a trypanocidal agent, led the authors to study the metabolism of red cells stored with this compound, the main objective of which was to define its applicability in TACD control. Ten units of human whole blood collected in CPDA-1 were divided into two equal satellite bags. One had "WR6026" (final concentration 62.5 $\mu$ g/ $\mathrm{mL}$ ) added and the other was used as a control, both were stored at $4^{\circ} \mathrm{C}$. At baseline, day 7, 14, 21 and 28, samples were taken for the following measurements: adenosine triphosphate (ATP), hemoglobin, electrolytes (sodium and potassium), gases ( $\mathrm{pO}$, and $\mathrm{pCO}_{2}$ ) and osmotic fragility. The results of tests and control were analyzed through parametric t-student test. The results were similar in both groups throughout the experiment except for the level of ATP on day 14, which presented significantly higher values in the tests when compared with the controls $(p=0.012)$. It was concluded that WR6026 does not interfere in the preservation and probably the viability of the erythrocytes also until day 28 of storage. Consequently the authors suggest that WR6026 could emerge as a colorless substitute for gentian violet in the control of TACD in endemic areas.
\end{abstract}

Key-words: Transfusion-associated Chagas' disease. Chemoprophylaxis. Aminoquinolone. Blood transfusion.

Resumo A inexistência de uma droga eficiente e incolor para esterilizar in vitro o sangue chagásico faz com que a violeta de genciana continue sendo desde 1953 a única substância empregada no controle da doença de Chagas transfusional. A recente descoberta da ação tripanosomicida da aminoquinolina WR 6026, estimulounos a pesquisar eventuais efeitos deletérios deste sal sobre o eritrócito preservado, com o objetivo se avaliar a conveniência de seu emprego no controle da doença de Chagas transfusional. Dez unidades de sangue total foram coletadas em bolsas duplas CPD-A1 e divididas em volumes iguais. Em uma das bolsas foram colocados $62.5 \mu \mathrm{g} / \mathrm{mL}$ de WR 6026 e ambas as bolsas estocadas a $4^{\circ} \mathrm{C}$. À zero hora, dos dias 7,14, 21 e 28 amostras foram retiradas de cada bolsa com e sem WR6026 e submetidas aos seguintes testes: dosagem de ATP, hemoglobina, eletrólitos ( $\mathrm{Na}$ e K), gases ( $\mathrm{PO} 2$ e pCO2) e curva de fragilidade osmótica. Os resultados foram similares nos dois grupos, com exceção do ATP que, no grupo teste, apresentou valores significamente maiores que os do grupo controle no $14^{\circ}$ dia de estocagem. Os resultados permitem concluir que o WR6026 não interfere na preservação e possivelmente na viabilidade do eritrócito durante a estocagem normal, sugerindo que este sal pode vir a ser o substituto incolor da violeta de genciana, no controle da doença de Chagas transfusional.

Palavras-chaves: Doença de Chagas associada à transfusão. Quimioprofilaxia. Aminoquinolina. Transfusão de sangue.

\footnotetext{
1. Faculdade de Medicina do Triângulo Mineiro. Uberaba, MG. 2. Universidade de Uberaba, Uberaba, MG. 3. Hemocentro Regional de Uberaba, Uberaba MG. 4. Laboratório de Investigação Médica da Faculdade de Medicina da Universidade de São Paulo. 5. Instituto Adolfo Lutz, São Paulo, SP. 6. Walter Reed Army Institute of Research, Silver Spring M.D. USA; 7. Instituto de Ciências Biológicas da Universidade Federal de Minas Gerais, Belo Horizonte, MG. Supported by Fundação de Amparo à Pesquisa do Estado de Minas Gerais - FAPEMIG (Proc. n CBS 0418/96) and UNDP (World Bank/WHO Special Programme for Research and Training in Tropical Disease (TRD ID 960326)

Address to: Dr. Helio Moraes-Souza. Hemocentro Regional de Uberaba. Av. Getúlio Guaritá 250, 38025-440 Uberaba, MG, Brazil

Tel: 5534 3312-5713; Fax: 5534 3312-5077

e-mail: helioms@zaz.Com.br

Recebido para publicação em 12/4/2002.
} 
Chagas' disease (American trypanosomiasis) is a zoonosis caused by the flagellate protozoan parasite Trypanosoma cruzi and affects approximately 18 million people in Central and South America ${ }^{32} 49$. It is estimated that up to 60 percent of these infected individuals have migrated to urban areas in both endemic and nonendemic countries and that approximately 100,000 T. cruzi-infected individuals are now living in North America, where three cases of transfusion-associated Chagas' disease (TACD) have been recently notified in immunocompromised patients 2224323849 .

The prevalence of $T$. cruzi infection among Latin American blood donors during the early 1980's and 1990's was approximately 7 and 3\%, respectively29 303649 . Nowadays, this prevalence has fallen to nearly one percent ${ }^{25}{ }^{36}$. Despite a gradual reduction in the seroprevalence of antibodies to T. cruzi in blood donors in regions such as Brazil, Uruguay and Guatemala, there has reportedly been a steady prevalence in other countries, for examples Bolivia, Argentina (north region), Paraguay and Mexico 15252932374950 . With the eradication in some countries of the blood-sucking triatomine insects that transmit T. cruzi, allogeneic blood transfusion has become the main mechanism underlying the continuity of the endemic disease 4950

Current strategies to prevent TACD include identification of potentially infected blood donors by questionnaire and serological screening tests, treatment of collected blood with gentian violet (GV) and also alternative prophylactic measures, such as filtration and irradiation of blood products 2 2131-33 36404244 .

Although having shown some promising initial results, photo irradiation (ultraviolet $A$ light and gammairradiation), did not demonstrate satisfactory data in further studies ${ }^{1} 233351$. Leukodepletion, using leukocyte filters, has reduced T. cruzi concentration in infected blood, but was not able to completely eliminate all the blood trypomastigotes ${ }^{31} 32$.

The application of a questionnaire prior to donation to identify individuals who might be infected with T. cruzi has been done with success in nonendemic areas, but may significantly reduce the blood supply in endemic areas $^{21932}$. Although there are more than ten available methods, serology can present conflicting results. Hence, strict quality control procedures are needed to rule out false results 27323446 .

In areas of high endemicity or in regions where serologic screening is not feasible, the risk of TACD may be reduced by the addition of GV in the collected blood 404449 . However, many restrictions have been made to the use of GV mainly due to its violet color; and possible mutagenic action ${ }^{18}$. Consequently, in the last four decades, over a thousand different drugs or natural products have been studied in order to identify a colorless, nontoxic, and efficient drug to prevent TACD that could eventually substitute gentian violet, however with no success up until now ${ }^{113641}$.

An aminoquinolone, Walter Reed n 6026 (WR6026) developed by the Walter Reed Institute (U.S.A) is a promising drug for visceral leishmaniosis treatment ${ }^{48}$ and has also been tested by a group of Brazilian scientists that reported its in vitro action at $62.5 \mu \mathrm{g} / \mathrm{mL}$ against bloodstream forms of $T_{\text {. cruzi }}{ }^{10}$. More recently, another group of Brazilian researchers showed that this same salt tested at different concentrations (ranging from 1 to $3.5 \mathrm{mg} / \mathrm{kg} /$ day) for a period of 28 days had an increasing efficacy up to $2 \mathrm{mg} / \mathrm{kg} /$ day after which it decreased with higher doses ${ }^{16}$.

In view of these studies, the authors considered it would be useful to investigate a hypothetical effect of WR6026 on red cell metabolism, in order to determine its applicability against TACD.

\section{MATERIAL AND METHODS}

Ten units of human whole blood were collected from ten normal donors (Hemocentro Regional de Uberaba) in double bags with citrate-phosphate-dextrose-adenine (CPDA-1) (Baxter, USA). After blood collection, 200mL of whole blood were transferred to the satellite bag (control). To the $300 \mathrm{~mL}$ remaining $18.75 \mathrm{mg}$ of WR6026 was added, with a final concentration of $62.5 \mu \mathrm{g} / \mathrm{mL}$ (test). Both bags were stored at $4^{\circ} \mathrm{C}$, and at day zero, $7,14,21$ and 28 samples were taken for the same determinations utilized in the previous study of metabolism and preservation of the erythrocyte added with $\mathrm{GV}^{35}$. These were:

a) adenosine triphosphate (ATP): measured in duplicate by Beutler's method $(1975)^{6}$.

The results are summarized in Tables 1 and 2 and Figures 1 to 3 . To compare these results with the authors' b) hemoglobin: by automated method using a Coulter T-890.

c) electrolytes (sodium and potassium), $\mathrm{pH}$ and gases $\left(\mathrm{pO}_{2}\right.$ and $\mathrm{pCO}_{2}$ ): automatic analyzer model IL1640 $\mathrm{pH} /$ blood gas/electrolytes (Instrumentation Laboratory SA - Milan, Italy).

d) osmotic fragility: using Dacie and Lewis' technique $(1975)^{12}$

Statistical analysis. The continuous numeric variables showed a normal distribution and were expressed as mean \pm S.D. Parametric T-student test was employed to compare the samples of control and those treated with WR6026 at each time of the experiment. Results were considered significant when $p<0.05^{39}$.

\section{RESULTS}

previous study, as mentioned above, they were grouped as follows: organic phosphates (Table 1) and, since the 
values of sodium, potassium, $\mathrm{pH}, \mathrm{pO}_{2}, \mathrm{pCO}_{2}$ and hemoglobin were uniform and without statistical significance, they were presented as mean values in a single table (Table 2). Osmotic fragility was presented in Figures 1 to 3.

Organic phosphate. Adenosine triphosphate (ATP): a gradual decrease on the ATP values was observed during the time of storage between both groups (control and test). However, on day 14, the ATP figures were significantly higher in samples added with the compound (Test) $(p=0.012)$ (Table 1).

Electrolytes. Potassium (K): this electrolyte showed a gradual increase during storage in both groups. Comparison between the two groups showed no significant differences with similar means throughout the experiment (Table 2).

Table 1 - Adenosine triphosphate in $\mu \mathrm{M} / \mathrm{g} \mathrm{Hb}$ on fresh (time zero) and stored blood (day 7, 14, 21 and 28), collected in CPDA1, treated with WR6026 (Test) and without WR6026 (control).

\begin{tabular}{|c|c|c|c|c|c|c|c|c|c|c|}
\hline \multirow[b]{2}{*}{ Sample } & \multicolumn{2}{|c|}{ Baseline } & \multicolumn{2}{|c|}{ Day 7} & \multicolumn{2}{|c|}{ Day 14} & \multicolumn{2}{|c|}{ Day 21} & \multicolumn{2}{|c|}{ Day 28} \\
\hline & $\mathrm{C}$ & $\mathrm{T}$ & C & $\mathrm{T}$ & C & $T$ & $\mathrm{C}$ & $\mathrm{T}$ & C & $\mathrm{T}$ \\
\hline 1 & 6.539 & 6.80 & 6.317 & 6.60 & 5.705 & 6.015 & 5.012 & 4.785 & 2.890 & 2.776 \\
\hline 2 & 6.387 & 6.610 & 6.170 & 6.386 & 5.525 & 6.333 & 4.980 & 5.012 & 2.228 & 3.319 \\
\hline 3 & 6.363 & 6.420 & 6.147 & 6.202 & 5.580 & 5.950 & 4.875 & 4.625 & 2.510 & 3.012 \\
\hline 4 & 6.428 & 6.459 & 6.210 & 6.240 & 5.690 & 5.985 & 5.015 & 4.530 & 3.280 & 3.152 \\
\hline 5 & 6.573 & 6.138 & 6.350 & 5.930 & 5.820 & 5.765 & 4.680 & 4.120 & 3.255 & 2.830 \\
\hline 6 & 6.150 & 5.988 & 5.970 & 5.735 & 5.235 & 5.420 & NP & NP & NP & NP \\
\hline 7 & 6.330 & 6.260 & 6.120 & 6.035 & 5.575 & 5.625 & NP & NP & NP & NP \\
\hline 8 & 6.135 & 6.920 & 5.930 & 6.800 & 5.390 & 6.585 & NP & NP & NP & NP \\
\hline 9 & 5.950 & 5.997 & 5.715 & 5.758 & 5.208 & 5.376 & NP & NP & NP & NP \\
\hline 10 & 6.280 & 6.420 & 6.035 & 6.280 & 5.480 & 5.895 & NP & NP & NP & NP \\
\hline Mean & 6.314 & 6.369 & 6.103 & 6.163 & 5.521 & $5.895^{\star}$ & 4.912 & 4.614 & 2.833 & 3.018 \\
\hline Stand. Deviation & 0.192 & 0.286 & 0.201 & 0.317 & 0.199 & 0.377 & 0.142 & 0.331 & 0.461 & 0.225 \\
\hline
\end{tabular}

$\mathrm{C}=$ control; $\mathrm{T}=$ test $\mathrm{NP}=$ not performed

${ }^{*} p=0.012$

Table 2 - Mean values of potassium, sodium, $\mathrm{pH}$, partial pressure of oxygen, partial pressure of carbon dioxide and hemoglobin, on fresh blood (baseline) and stored (day 7, 14, 21 and 28), collected in CPD-A1 and treated with WR6026 (Test) and without WR6026 (Control).

\begin{tabular}{|c|c|c|c|c|c|c|c|c|c|c|}
\hline \multirow[b]{2}{*}{ Parameter } & \multicolumn{2}{|c|}{ Baseline } & \multicolumn{2}{|c|}{ Day 7} & \multicolumn{2}{|c|}{ Day 14} & \multicolumn{2}{|c|}{ Day 21} & \multicolumn{2}{|c|}{ Day 28} \\
\hline & $\mathrm{C}$ & $\mathrm{T}$ & $\mathrm{C}$ & $\mathrm{T}$ & $\mathrm{C}$ & $\mathrm{T}$ & $\mathrm{C}$ & $\mathrm{T}$ & $\mathrm{C}$ & $T$ \\
\hline Potassium & 3.48 & 3.72 & 10.75 & 11.72 & 16.06 & 16.56 & 18.40 & 18.10 & 23.42 & 24.14 \\
\hline $\mathrm{pH}$ & 6.995 & 6.980 & 6.741 & 6.736 & 6.591 & 6.584 & 6.498 & 6.526 & 6.398 & 6.412 \\
\hline pO2 $(\mathrm{mmHg})$ & 30.5 & 29.3 & 35.3 & 27.1 & 39.5 & 36.3 & 49.6 & 51.4 & 60.6 & 55.2 \\
\hline
\end{tabular}

Sodium ( $\mathrm{Na}$ ): The mean Na values presented a slight decrease during storage. On comparing the two groups, slightly lower levels were observed, although these were not statistically significant, between the samples with and without added WR6026 (Table 2).

$\mathrm{pH}$, Gases and Hemoglobin. $\mathrm{pH}$ : the $\mathrm{pH}$ presented a discreet and gradual decrease during storage. Both groups showed a similar behavior during the entire experiment (Table 2).

Partial pressure of oxygen $\left(\mathrm{pO}_{2}\right)$ : in both groups $\mathrm{pO}_{2}$ presented gradual increase reaching duplicate values at the end of week 4 of storage. However, there were no differences between the two groups (Table 2).

Partial pressure of carbonic gas $\left(\mathrm{pCO}_{2}\right)$ : the $\mathrm{pCO}_{2}$ showed a gradual increase at the end of the $3^{\text {rd }}$ week with a discreet fall on day 28 of storage. Comparison between the two groups did not show any significant difference during the experiment (Table 2).

Hemoglobin: the mean values of hemoglobin presented a discreet and gradual fall throughout the experiment. There were no statistical significant differences between the groups (Test and Control) (Table 2).

Osmotic fragility. Osmotic fragility was tested at concentrations of 0.00 to $0.80 \%$ and of sodium chloride $(\mathrm{NaCl})$. Similar levels of hemolysis were presented throughout the experiment in both groups with no evidence of a statistically significant difference. Figures 1 to 3 show the mean values of hemolysis at each dilution, at baseline, day 14 and 28 for both groups (test and control) and also in a standard group at baseline. 
Base line

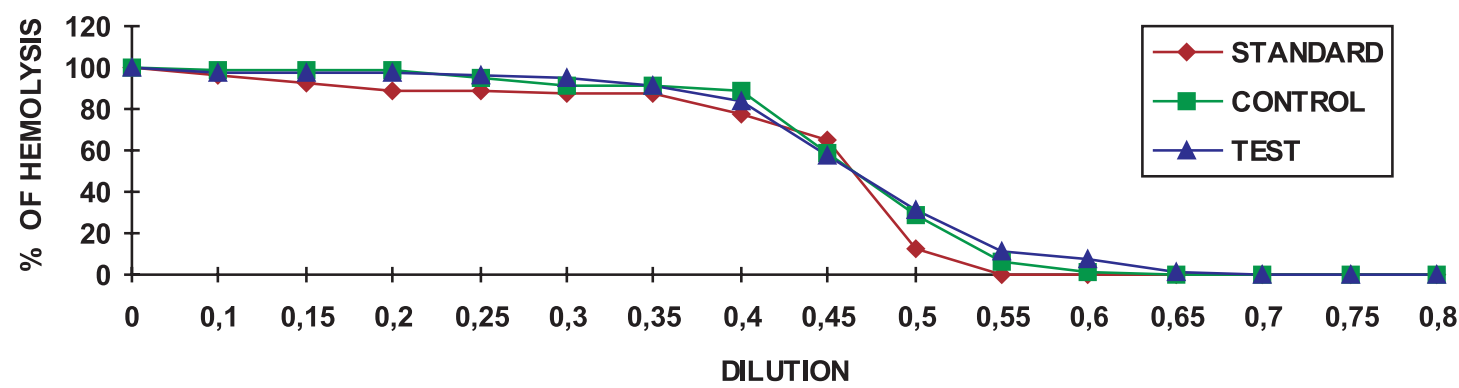

Figure 1 - Osmotic fragility - Curve of medium values of hemolysis of fresh blood collected in heparin (standard), stored in CPD-A1 with the compound WR6026 (Test) and without it (control) at baseline.

DAY 14

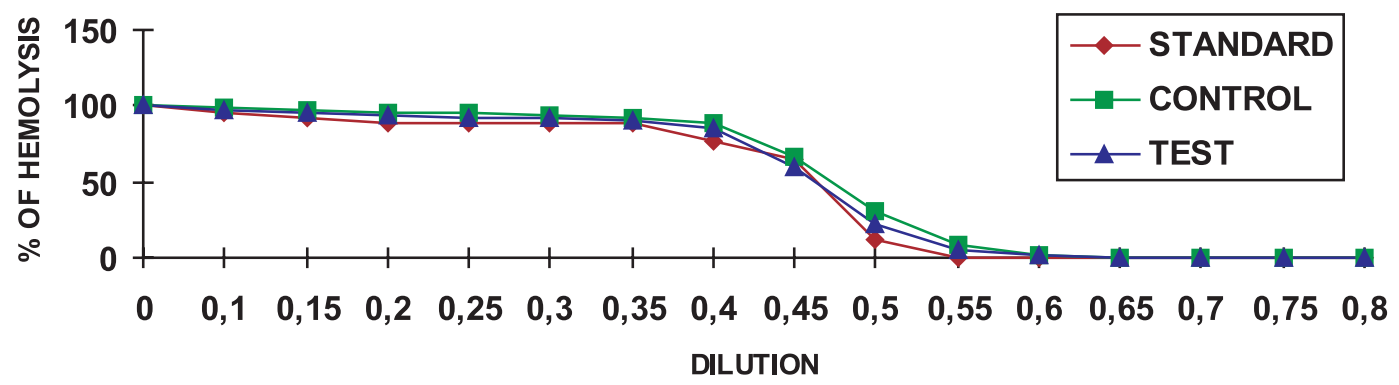

Figure 2- Osmotic fragility - Curve of mean values of hemolysis of fresh blood collected in heparin (standard), stored in CPD-A1 with the compound WR6026 (Test) and without compound (control) on day 14.

DAY 28

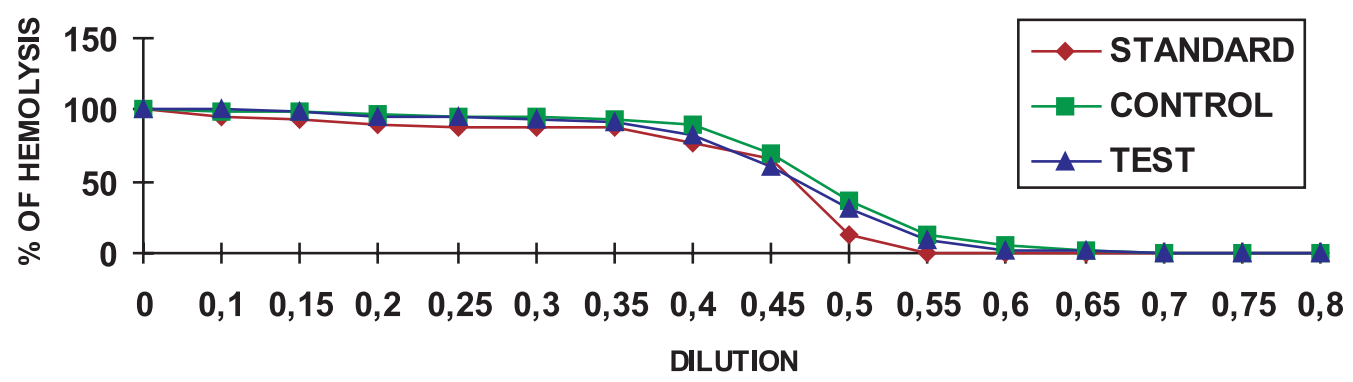

Figure 3 - Osmotic fraqility - Curve of mean values of hemolysis of fresh blood collected in heparin (standard), stored in CPD-A1 with the compound WR6026 (Test) and without compound (control) on day 28. 


\section{DISCUSSION}

As previously mentioned, the current strategies to prevent TACD include the identification of infected blood donors or treatment of collected blood 2323751.

The lack of a safe and efficient method for the control of TACD and the evidence that WR6026 has been shown to have a strong trypanocidal action, motivated the present study, with the main objective of investigating possible metabolic alterations on the red cells stored for transfusions and with the compound WR6026 added, in order to determine the possibility of its use in TACD control.

The following parameters were studied: ATP, K, Na, $\mathrm{pH}, \mathrm{pCO}_{2}, \mathrm{pO}_{2}$, hemoglobin and osmotic fragility. These parameters have been widely used to investigate red cell preservation and viability in stored blood 8202637 . Furthermore, the same parameters have been used in a previous study with gentian violet ${ }^{35}$. The relationship between ATP levels and viability of erythrocytes in vitro was emphatically defended in 1967, by Dern and cols who did not consider stored erythrocytes with ATP levels below $1.5 \mu \mathrm{M} / \mathrm{g} \mathrm{Hb}$ to be viable ${ }^{14}$. The present study demonstrated a decrease in the ATP levels, but at the end of week 4, they were approximately two times superior to the lower limits established by the authors, suggesting a good level of erythrocyte viability.

In this study, a variation was observed in potassium that ranged from 1.5 to $8 \mathrm{mEq} / \mathrm{L}$ (mean $5 \mathrm{mEq} / \mathrm{L}$ ), with an expected normal increase between 5 to $10 \mathrm{mEq} / \mathrm{L}$ per week, through blood storage ${ }^{456}$. Such a result may be considered indirect evidence of a poor hemolysis state in blood storage.

The $\mathrm{pH}$ values found in the authors' experiments were slightly inferior to those presented in standard tables regarding component preservation ${ }^{3}$. However, they were similar to those found in the authors' previous studies ${ }^{535}$. A possible hypothesis to explain these results is the fact that the analyses were performed at room temperature $\left(24^{\circ} \mathrm{C}\right)$, whereas in the literature the same analysis was carried out at a storage temperature of $4^{\circ} \mathrm{C}$; a condition which increases $\mathrm{pH}$ by approximately five decimeters ${ }^{6}{ }^{45}$.

When studying gases, the experiment showed concordant results in both groups and also with those of previous studies ${ }^{317}$. The gradual elevation of $\mathrm{pO}_{2}$ values is possibly explained by the increase of fixation of $\mathrm{O}_{2}$ by hemoglobin since there was a 2.3DPG decrease, and also by oxygen diffusion through the bags 202647 . The increased pCO2 level at the end of week 3 is most probably due to the release of $\mathrm{HCO}_{3}^{-}$and its decrease by day 28 may be explained by the permeability of the plastic bags to $\mathrm{CO}_{2}$, thus allowing its diffusion to the environment ${ }^{20}$.

A discreet fall in the mean values of hemoglobin in both groups was noticed. However, the slight potassium increase, similar or inferior to those values reported in the literature, is strong evidence of absence of important hemolysis in the samples. Additionally, the free hemoglobin analyzed in samples up to week 2 was within normal values (data not shown). Furthermore, Chiari and cols ${ }^{10}$ did not notice any sign of hemolysis in samples utilized when studying the trypanocidal activity of WR $6026^{10}$.

As demonstrated, the osmotic fragility did not present any significant alteration during the four weeks of storage. Based on the studies, which correlate curves of normal fragility to an adequate preservation and good viability of stored blood ${ }^{13}$, the present results reinforce the evidence that WR6026 does not interfere with the viability of the erythrocytes.

Based on the absence of significant alterations over the eight parameters analyzed, it was possible to conclude that WR6026 does not interfere with red cell preservation and possibly nor in the viability of the erythrocyte until day 28 . Recent studies have showed a slight and moderate increase of methahemoglobin and also nephrotoxicity related to doses and time of utilization of the salt, generally superior to $2 \mathrm{mg} / \mathrm{kg} /$ day for a period of 28 days ${ }^{16} 284348$. This dosage in vivo corresponds to $140 \mathrm{mg} / \mathrm{kg} /$ day or $3920 \mathrm{mg}$ for 28 days for an adult of $70 \mathrm{~kg}$. In the authors' studies each blood bag with $300 \mathrm{ml}$ of whole blood contained $18.75 \mathrm{mg}$ of WR6026, which corresponds to a dose 20 times smaller than that demonstrated to be nephrotoxic. These findings enable the prediction that this compound may become a useful and colorless substitute for gentian violet in the control of TACD.

\section{ACKNOWLEDGEMENTS}

The authors thank Dr. Daniel Ferreira Cunha for critical review of the statistical analysis, as well as Mrs. Heloisa Vieira Cabariti for technical help in preparing the tables and figures.

\section{REFERENCES}

1. Amato Neto V, Pasternak J, Matsubara L, Hammerschlak N, Carignani FL. Tentativas de uso de raios gama para prevenir infecção transfusional pelo Trypanosoma cruzi. Revista da Sociedade Brasileira de Medicina Tropical 29:613-614, 1996.

2. Appleman MD, Shulman IA, Saxena S, Kirchhoff LV. Use of a questionnaire to identify potential blood donors at risk for infection with Trypanosoma cruzi. Transfusion 33:61-64, 1993.
3. American Association of Blood Banks. Technical Manual. Walker $\mathrm{RH}$ (ed) Bethesda, Maryland, 11 $11^{\text {th }}$ edition, 1993.

4. Bailey DN, Bove JR. Chemical and hematological changes in stored CPD blood. Transfusion 15:244-249, 1975.

5. Barretto OCOP, Nonoyama K, Sawatani E, Tanaka K, Okumura $\mathrm{Y}$, Jamra M. Viabilidade do sangue conservado em recipientes 
de várias procedências. Revista da Associação Médica Brasileira 29:102-105, 1983

6. Beutler E. Red cell metabolism. A manual of biochemical methods. $2^{\text {nd }}$ edition. New York, Grune \& Stratton, 1975.

7. Beutler $E$, Duron O. Factors influencing the preservation of red ATP on storage. Folia Haematologica 83:509-515, 1965.

8. Beutler E, West C. Storage of red cell concentrates in CPD-A2 for 42 and 49 days. Journal of Laboratory and Clinical Medicine 102:53-62, 1983.

9. Bianco RP, Santarelli MT y miembros de la Sociedad Argentina de Hemoterapia e Imunohematologia. Medicina 53:491-496, 1993.

10. Chiari E, Oliveira AB. Chemoprophylaxis in Chagas' Disease: Potential use of natural products of plant origin and related synthetic compounds. Revista da Sociedade Brasileira de Medicina Tropical 27 (supl):129-130, 1994.

11. Chiari E, Oliveira AB, Prado MAF, Alves RJ, Galvão LMC, Araújo FG. Potential use of WR6026 as prophylaxis against transfusiontransmitted American Trypanosomiasis. Antimicrobial Agents Chemotherapy 40: 613-615, 1996.

12. Dacie JV, Lewis SM. Practical Haematology, $5^{\text {th }}$ edition. Edinburg, Churchill Livingstone. 1975.

13. Danon D, Frei YF, Rimon A, Ben-David A. Simple rapid osmotic fragility test proposed as a routine in blood banks. Transfusion 4:339-342, 1964.

14. Dern RJ, Brewer GJ , Wiorkowski JJ. Studies on the preservation of human blood. II. the relationship of erythrocyte adenosine triphosphate levels and other in vitro measure to red cell storage ability. Journal of Laboratory and Clinical Medicine 69:968-978, 1967

15. Dias JCP, Coura JR, Epidemiologia. In: Dias JCP, Coura JR (eds) Clínica e terapêutica da doença de Chagas. Editora da Fundação do Instituto Oswaldo Cruz, Rio de Janeiro, 1997

16. Dietze R, Carvalho SFG, Valli LC, Berman J, Brewer T, Milhous W, Sanchez J, Schuster B, Grogl M. Phase 2 trial of WR6026 , an orally administered 8-aminoquinoline, in the treatment of visceral Leishmaniasis caused by Leishmania chagasi. American Journal of Tropical Medicine and Hygiene 65:685-689, 2001.

17. Dobashi PN. Contribuição ao estudo do equilíbrio ácido-básico e transporte de oxigênio, no sangue estocado em solução de ácido-citrato-dextrose (ACD) Tese de Mestrado, Escola Paulista de Medicina, São Paulo, 1978.

18. Docampo R, Moreno SNJ. The metabolism and mode of action of gentian violet. Drug and Metabolic Reviews 22:161-178, 1990.

19. Dodd RY. scaling the heights. Transfusion 35:186-187, 1995.

20. Fagiolo E, Mores N, Pelliccetti A, Gozzo ML, Zuppi C, Littarru GP. Biochemical parameters to assess viability of blood. Folia Haematologica Internationales Magazin Fur Klinische Und Morphologische Blutforschung 113:783-789, 1986.

21. Ferreira AW. Tests for Chagas disease serodiagnosis: a review. In: Wendel S, Brener Z, Camargo ME (eds) Chagas' disease (American Trypanosomiasis): Its Impact on Transfusion and Clinical Medicine. Sociedade Brasileira de Hematologia e Hemoterapia, São Paulo, 179-193, 1992.

22. Geiseler PJ, Ito JI, Tegtmeier BR, Kerndt PR, Krance R. Fulminant Chagas' disease in bone marrow transplantation. In: Abstract of the at $27^{\text {th }}$ Interscience Conference on Antimicrobial Agents and
Chemotherapy. American Society for Microbiology. Washington, DC, p4181, 1987.

23. Gottlieb P, Ben-Hur E, Lustigman S, Margolis-Nunno H, Harowitz B. Parasite inactivation in red blood cells and platelet concentrates by photodynamic treatment. Transfusion 34:43S, 1994.

24. Grant IH, Gold JW, Wittner M, Tonowitz HB, Nathan CN, Mayer K, Reich L, Wollner N, Steinherz L, Ghavimi F, O'Reilly RJ, Armstrong D. Transfusion-associated acute Chagas disease acquired in the United States. Annals of Internal Medicine 111:849-851, 1989

25. Guzman Bracho C, Garcia Garcia L, Floriani Verdugo J, Guerrero Martinez S, Torres Cosme M, Ramirez Melgar C, Castrejon V. Risk of transmission of Trypanosoma cruzi by blood transfusion in Mexico. Revista Panamericana de Salud Publica 94-99, 1998.

26. Högman CF, De Verdier CH, Eriksson L, Sandhagen B. Effects of oxygen and mixing on red cells stored in plastic bags at +4 degrees $^{c}$. Biomedica Biochimica Acta 46: 2-3, 1987.

27. Langhi DM Jr, Bordin JO, Castelo A, Walter SD, Moraes-Souza $\mathrm{H}$, Stumpf RJ. The application of latent class analysis for diagnostic test validation of chronic Trypanosoma cruzi infection in blood donors. Brazilian Journal of Infectious Diseases 6:181-187, 2002.

28. Levine BS. 13-week oral toxicity study of WR6026 with a 13week recovery period in dogs. US Army Medical Research and Development Command Contract \# DAMD17-92-C-2001.

29. Monteon-Padilla VM, Hernandez-Becerril N, Guzman-Bracho C, Rosales-Encina JL, Reyes-Lopez PA. American trypanosomiasis (Chagas' disease) and blood banking in Mexico City: seroprevalence and its potential transfusional transmission risk. Archives of Medical Research 30: 393-398, 1999.

30. Moraes-Souza H. Estudo do metabolismo e viabilidade do sangue fresco e preservado tratado pela violeta de genciana. Tese de Doutorado. Escola Paulista de Medicina, São Paulo, SP,1985.

31. Moraes-Souza H. Transmissão transfusional da Doença da Chagas. Revista de Patologia Tropical 29 (supl):91-100 2000.

32. Moraes-Souza H, Bordin JO. Strategies for prevention of transfusion-associated Chagas' disease. Transfusion Medicine Reviews 10:161-170, 1996.

33. Moraes-Souza H, Bordin JO, Bardossy L, MacPherson DW, Blajchman MA. Prevention of transfusion-associated Chagas' disease: efficacy of white cell-reduction filters in removing Trypanosoma cruzi from infected blood. Transfusion 35:723-726, 1995.

34. Moraes-Souza H, Bordin JO, Bardossy L, Blajchman MA. Treatment of $T$. cruzi infected human platelet concentrates with aminomethyltrimethyl psoralen (AMT) and ultraviolet A (UV-A) light. Revista da Sociedade Brasileira de Medicina Tropical, 29:47-49, 1996.

35. Moraes-Souza H, Gontijo ED, Bonametti AM, Lopes MH, Wendel S. Atenção médica e candidatos a doadores de sangue em centros urbanos: inserção no sistema de saúde (provas sorológicas positivas e inconclusivas para Doença de Chagas). Relatório de Oficina de Trabalho. Revista da Sociedade Brasileira de Medicina Tropical 33:113-115 2000.

36. Moraes-Souza H, Kerbauy J, Barretto OCP, Pühler GMP Nonoyama K, Juliano $Y$. Metabolism and preservation of fresh and stored erythrocytes in blood treated with gentian violet. Brazilian Journal of Medical and Biological Research 21:241-246, 1988. 
37. Moraes-Souza H, Ramirez LE and Bordin JO. Doença de Chagas transfusional: medidas de controle. In: Dias JCP, Coura JR (eds) Clínica e terapêutica da doença de Chagas. Editora da Fundação do Instituto Oswaldo Cruz, Rio de Janeiro, 1997.

38. Nakao K, Wada T, Kamiyama T, Nakao M, Nagano K. A direct relationship between adenosine triphosphate-level and in vivo viability of erythrocytes. Nature 194:877-878, 1962.

39. Nickerson P, Orr P, Schroeder ML, Sekla L, Johnston JB. Transfusion-associated Trypanosoma cruzi in a non-endemic area. Annals of Internal Medicine 111:851-853 1989.

40. Noether GE. Introdução à estatística: Uma abordagem não paramétrica. Rodrigues FW, Cordani LK (eds) Guanabara Dois. $2^{\mathrm{a}}$ edição. Rio de Janeiro, 1983.

41. Nussenzweig V, Sonntag R, Biancalana A, Pedreira de Freitas $\mathrm{JL}$, Amato Neto V, Kloetzel J. Action of certain dyes on T. cruzi in vitro. The use of gentian violet to prevent the transmission of Chagas' disease by blood transfusion. Hospital 44: 731-744, 1953.

42. Organização Mundial de Saúde. Special Programme for Research and Training in Tropical Diseases. Meeting on development on trypanocidal compounds for sterilization of blood. TDR/CHA/BS/ 84.3; 1-14. 1984.

43. Organizacão Panamericana de Saúde. Taller sobre control de calidad en serologia de bancos de sangre. OPS/HCP/HCT/96/ 79, 1996.

44. Petty BG, Black JR, Hendrix CW, Lewis LD, Basiakos Y, Feinberg J, Pattison DG, Hafner R. Escalating multiple-dose safety and tolerance study of oral WR6026 in HIV-infected subjects: AIDS clinical trials group 173. Journal of Acquired Immune Deficiency Syndrome 21:26-32, 1999.

45. Ramirez LE, Lages-Silva E, Pianetti GM, Rabelo RMC, Bordin JO, Moraes-Souza H. Prevention of transfusion-associated
Chagas' disease by sterilization of $T$. cruzi-infected blood with gentian violet, ascorbic acid and light. Transfusion 35: 226-230, 1995.

46. Rosenthal TB. Effect of temperature on $\mathrm{pH}$ of blood and plasma in vitro. Journal of Biological Chemistry 173:25-30, 1948.

47. Salles NA, Sabino EC, Cliquet MG, Eley-Neto J, Mayer A, Almeida-Neto C, Mendonça MC, Dorliach-Llacer, Chamone DF, Saéz-Alquézar A. Risk of exposure to Chagas' disease among seroreactive Brazilian blood donors. Transfusion 36:969-973, 1996.

48. Sandhagen B, Högman CF, de Verdier CH, Eriksson L. Distribution of blood gases, glucose and lactate within stored blood units. Vox Sanguinis 55:139-142, 1988.

49. Sherwood JA, Gachihi GS, Muiagi RK, Skilman DR, Mugo M, Rashid JR, Wasunna KMA, Were JBO, Kasili SK, Mbugua JM, Kirigi G, Schaefer KU, Oster CN, Fleckenstein LL, Berman JD, Brewer TJ, Roberts CR, Johnson A J, Schuster BG. Phase 2 efficacy trial of an oral 8- aminoquinoline (WR 6026) for treatment of visceral Leishmaniosis. Clinical and Infectious Diseases 19: 1034-1039, 1994.

50. Schmuñis GA. Trypanosoma cruzi, the etiologic agent of Chagas' disease: status in the blood supply in endemic and nonendemic countries. Transfusion 31:547-557, 1991.

51. Schmuñis GA. Tripanosomíase Americana: seu impacto nas Américas e perspectivas de eliminação. In: Dias JCP, Coura JR (eds) Clínica e terapêutica da doença de Chagas. Editora da Fundação do Instituto Oswaldo Cruz, Rio de Janeiro, 1997.

52. Takeda GK, Campos R, Kieffer J, Moreira AA, Amato Neto V, Castilho VL, Pinto PL, Duarte MI. Ação de raios gama sobre formas sanguícolas de Trypanosoma cruzi. Estudo experimental em camundongos. Revista do Instituto de Medicina Tropical São Paulo 28:15-18, 1986. 